\title{
Crescentiella-microbial-cement microframeworks in the Upper Jurassic reefs of the Crimean Peninsula
}

\author{
Marcin Krajewski ${ }^{1} \cdot$ Felix Schlagintweit ${ }^{2}$
}

Received: 8 February 2018 / Accepted: 25 May 2018 / Published online: 9 June 2018

(c) The Author(s) 2018

\begin{abstract}
In the Upper Jurassic reef successions of the Crimean Peninsula (Sudak and Jalta areas), the microencruster Crescentiella morronensis (Crescenti), microbialites, and multiple generations of cements, form microframeworks. They were observed in two stages of the carbonate platform evolution, in the Middle-Upper Oxfordian, and in the Upper Kimmeridgian-Tithonian. Generally, in both stages, the features of the microframeworks are similar and consist of densely packed Crescentiella associated with microbialites and branched colonies of the sclerosponge Neuropora lusitanica Termier. The difference between the occurrences of the two stages is the variable amount of nubecularid foraminifera and enigmatic tube-shaped structures forming the central cavities of Crescentiella. The Crescentiella-microbial-cement microframeworks formed under phreatic conditions in the upper slope and seaward marginal depositional settings where intensive synsedimentary cementation took place. They formed in the initial stages of long cycles of restoration and blooming of the reefs. The late Jurassic examples resemble the Permian algae-microbial-cement reefs as well as the Triassic Tubiphytes and cement crust-dominated reefs. Concurrently, all these examples formed a transitional facies zone between typical slope facies to shallow subtidal platform margin facies characterized by high taxonomic diversity of calcified sponges, corals, and microencrusters forming the principal part of the reefs.
\end{abstract}

Keywords Microencrusters $\cdot$ Crescentiella $\cdot$ Microbialites $\cdot$ Cement crusts $\cdot$ Reefs $\cdot$ Late Jurassic $\cdot$ Crimea

\section{Introduction}

In the Tethyan realm and its margins, the Late Jurassic was a time of intensive growth of reefs. The North Tethys/Atlantic reefs that developed on extensive ramp-type platforms can be assigned to three broad compositional types: (1) coraldominated, (2) siliceous sponge-dominated, and (3) microbialite-dominated (e.g., Leinfelder et al. 2002). In contrast hereto, the isolated reefs growing at the margins of intraTethyan platforms were dominated mostly by mixed, coralscalcified sponges (including stromatoporoids and chaetetids) facies (e.g., Turnšek et al. 1981; Leinfelder et al. 2002, 2005; Vlahović et al. 2005; Ivanova et al. 2008; Rusciadelli et al. 2011; Della Porta et al. 2013; Hoffmann et al. 2017). Their

Marcin Krajewski

kramar@geol.agh.edu.pl

1 Faculty of Geology, Geophysics and Environmental Protection, AGH University of Science and Technology, Al. Mickiewicza 30, 30-059 Kraków, Poland

2 Denningerstr. 46, 81679 Munich, Germany characteristic lateral assemblages allow the zonation of these reef complexes, corresponding to fore-reef, reef crest, and flat to back-reef environments.

Unlike other Upper Jurassic reefs from both western and southern Europe, which have deserved a number of detailed studies, the reefs from the Crimea-Caucasus region have received less attention, as yet. Most of the studies were mainly descriptive, whereas detailed data were rarely published. For the Southern Crimea, Nikishin et al. (2015a, b) presented a ternary plot showing the Late Jurassic reefbuilding communities of Crimean reefs based upon data from, among others, the Ai-Petri Massif (Krajewski 2008, 2010). The main reef-builders were microbial mats/microencrusters, corals and sponges, which correspond to assemblages known from the Caucasus Mts. (e.g., Bendukidze 1982; Guo et al. 2011). In the Crimea Mts, the most spectacular Oxfordian coral reefs are reported from the Sudak area (e.g., Muratov 1973; Geister et al. 2007; Nikishin et al. 2015b) although detailed studies on their facies and microfacies have so far not been published. A few papers with details concerning Upper Jurassic reefs were published from 
the Demerdzhi Plateau (Piskunov et al. 2012; Rud'ko et al. 2014, 2017), the Mt. Pakhkal-Kaya (Baraboshkin and Piskunov 2010) as well as the Jalta and the Ai-Petri massifs (Krajewski and Olszewska 2006; Krajewski 2008, 2010; Bucur et al. 2014; Schlagintweit and Krajewski 2015). These publications describe several Upper Kimmeridgian-Berriasian Štramberk-type shallow-water facies and microfacies documenting the development of Crimean carbonate platform.

In recent papers dealing with both the Tethyan northern shelf and the intra-Tethyan platforms, still-growing attention is paid to the presence and the role of a wide spectrum of socalled "microencrusters" (e.g., Crescentiella, bacinellid fabrics, Thaumatoporella, Radiomura, Lithocodium, Iberopora, etc., e.g., Schmid 1996; Leinfelder et al. 1996; Ivanova et al. 2008; Pleş et al. 2013, 2017; Kaya and Altiner 2015; Hoffmann et al. 2017) in the formation of reef frameworks. Apart from microbial crusts, these microencrusters were important components of coral and sponge reefs as secondary reefbuilders. Sometimes they form microbial-microencruster boundstones with a significant content of early cements. Late Jurassic to earliest Cretaceous microbial-microencrustercement-boundstones (microframeworks) assigned to outer margin-upper slope depositional settings have been reported from various intra-Tethyan (mostly southern Tethyan) platform carbonates: Austria (Schlagintweit and Gawlick 2008, Plassen Limestone), Bulgaria, Czech Republic and Poland (Ivanova et al. 2008; Hoffmann et al. 2017, Štramberk-type Limestone), Romania (Pleş et al. 2013, 2017), Italy (Rusciadelli et al. 2011, e.g., Table 1, Ellipsactinia Limestone), Turkey (Kaya and Altiner 2015) and Japan (Shiraishi and Kano 2004; Ohga et al. 2013, Torinosu Limestone). For a paleogeographic sketch displaying these occurrences in the western part of the Tethys see Fig. 11 in Kaya and Altiner (2015). In terms of microfacies and micro-/macrobiota assemblages, they differ from time-equivalent ramp deposits of the European northern Tethyan margin (see Leinfelder et al. 1994, 2002).

A common and widespread taxon of microencruster inhabiting the Upper Jurassic-Lower Cretaceous platforms is Crescentiella (former Tubiphytes) morronensis (Crescenti 1969) (Senowbari-Daryan et al. 2008, for details). It represents an enigmatic microorganism of controversial systematic position (e.g., Flügel 1981; Schmid 1995; SenowbariDaryan et al. 2008; Kaya and Altiner 2015; Pleş et al. 2017) interpreted as encrustation or symbiosis between nubecularid foraminifera or enigmatic, spar-filled, tube-shaped structures and cyanobacteria where foraminifera, tubes and/ or other biogenic components provide a substrate for the growth of microbialites.

A significant share of Crescentiella in the formation of reefs, besides the typical reef-builders, was noticed by, e.g., Schlagintweit and Gawlick (2008) who proposed a new type of Upper Jurassic reefs (or part of the reefs) dominated by microencrusters-cement microframeworks, based upon data from the Northern Calcareous Alps of Austria. Less common is the pure dominance of Crescentiella, which is the case described and discussed in the present paper. It must be emphasized that a significant contribution of Crescentiella in microframework building was described also from the Tethyan northern shelf (Germany, southern Poland), where Oxfordian microbial-Crescentiella boundstone facies (Tubiphytes reefs) occurs (e.g., Pomoni-Papaioannou et al. 1989; Leinfelder et al. 1994; Matyszkiewicz 1997; Krajewski et al. 2016). For example, in southern Poland, such facies was found on the slopes of grabens active in Late Jurassic times, where the marine cements common in microbial-Crescentiella boundstones were accompanied by similarly abundant, stromatactis-like cavities (Matyszkiewicz 1997; Olchowy 2011; Matyszkiewicz et al. 2012; Krajewski et al. 2016).

In the Upper Jurassic reef successions of the Crimean Peninsula, reef facies were observed where Crescentiella, microbial crusts and cements were prevailing components thereby forming microframeworks. Such structures have so far not been described in detail from the Crimea-Caucasus region. Hence, the following paper aims to characterize such microframework based on data from two typical occurrences of Late Jurassic reefs in the Crimea. Furthermore, the position and the role of these Upper Jurassic microframeworks in the reef formation will be discussed.

\section{Location and geological setting}

The study area is located along the southwestern shoreline of the Crimean Peninsula, in the Sudak and the Jalta areas (Fig. 1). The core of the Crimea Mts. is formed by sedimentary rocks ranging from Triassic to Lower Cretaceous in age (e.g., Muratov 1973; Mileev et al. 2006; Krajewski and Olszewska 2007; Nikishin et al. 2015a, b; Arkadiev et al. 2018). Both the age and the evolution of particular tectonic units however still remain controversial (Mileev et al. 2006; Yudin et al. 2015; Oszczypko et al. 2017). According to Nikishin et al. (2015b), these sedimentary rocks represent three major mega-sequences: (a) Triassic-Early Jurassic; (b) Aalenian-Bathonian; and (c) Callovian-Berriasian. The latter mega-sequence includes three tectonic units: (1) the Southern Crimean Shelf Basin, (2) the Sudak Deepwater Trough, and (3) the Alchak-Kaya Shelf Basin at the northern margin of the Shatsky Ridge. These authors divide the Southern Crimean Shelf Basin into a Callovian-Oxfordian syn-rift sequence (Sudak Series) and a Kimmeridgian-Berriasian post-rift succession (Yaila Series) (Nikishin et al. 2015b).

The field studies were run in the two regions of Upper Jurassic reefs occurrences: in the vicinity of Sudak town where Upper Jurassic deposits belong to the Sudak Series 


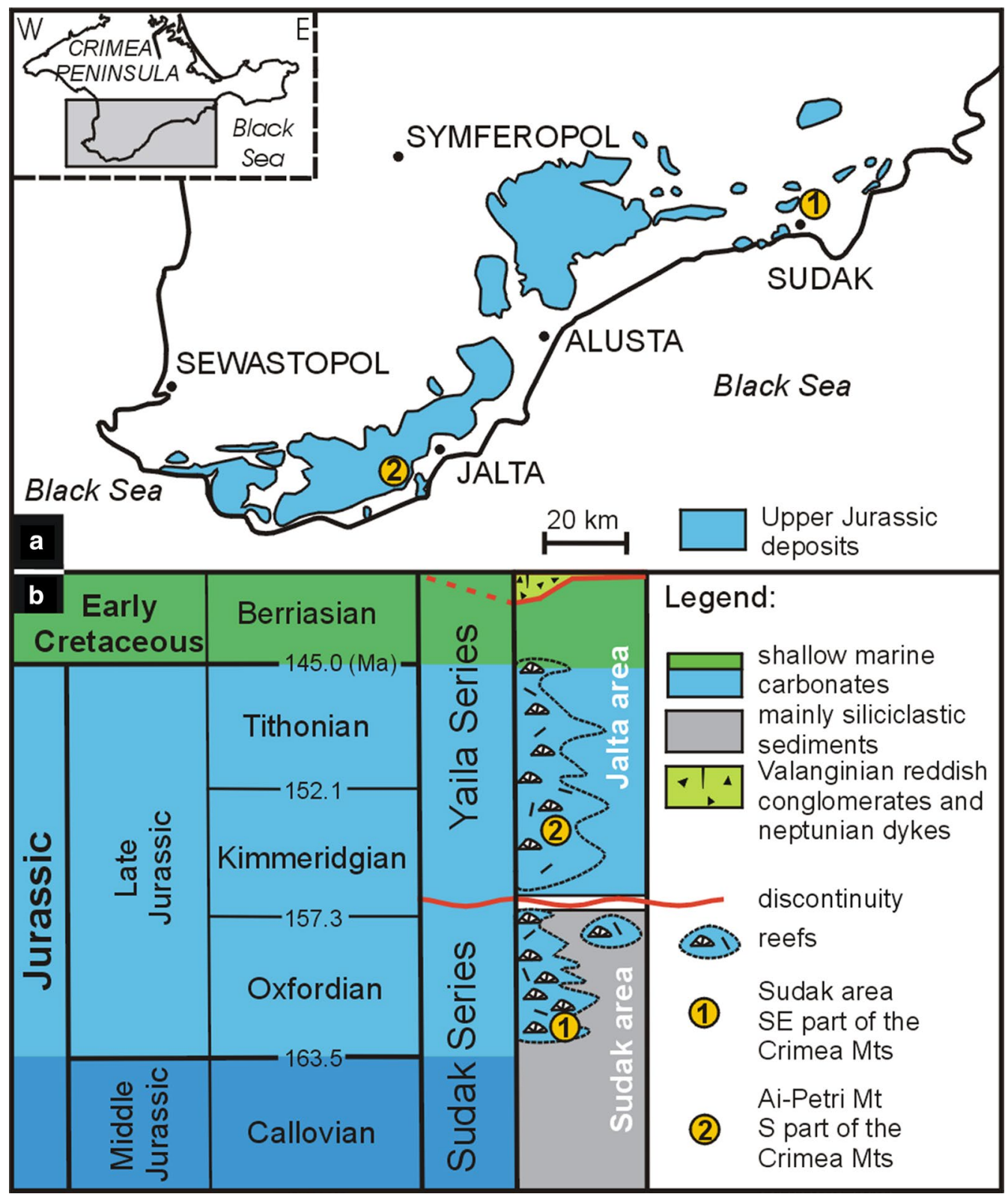

Fig. 1 a Location map of the study areas. b General Jurassic lithostratigraphy of the Crimean Mountains with position of the studied reefs (Sudak and Jalta area). Modified from Mileev et al. (2006) and Krajewski (2010)

and in the vicinity of Jalta town where the Ai-Petri Massif is built of sedimentary rocks of the Yaila Series (Fig. 1). According to Nikishin et al. (2015b), the reefs observed in the Sudak region represent a fragment of the Upper Oxfordian reef belt extending along the northern margin of the Shatsky Ridge carbonate platform. These reefs are regarded as close analogues to the Late Jurassic reefs found in the Shatsky Ridge (Afanasenkov et al. 2005; Guo et al. 2011). The Ai-Petri Massif is a spectacular example of the Late Kimmeridgian-Tithonian reef complex (Krajewski and Olszewska 2006, 2007) resembling the Štramberk-type reefs well known from the Pontides, Moesia, Southern Carpathian, Polish and Czech Outer Carpathian, Southern Crimea and the Northern Caucasus Mts (e.g., Matyszkiewicz and Słomka 2004; Bucur and Săsăran 2005; Ivanova et al. 2008; Guo et al. 2011; Piskunov et al. 2012; Pleş et al. 2013; Kaya and Altiner 2015; Kołodziej 2015; Strzeboński et al. 2017; Hoffmann et al. 2017; Vincent et al. 2018). The main part of the Late Jurassic successions from the Crimean Mts. was deposited onto the marginal part of the epicontinental basin, which rimmed the northern margin of the Tethys Ocean (Golonka 2004; Nikishin et al. 2015a). 


\section{Materials and methods}

The rock samples were collected in the years 2005-2012. The outcropping massifs have generally very steep to vertical walls, which hamper facies mapping (Fig. 2). Sometimes the structures of the reefs are poorly visible due to their massive character as a result of strong cementation. In both the Sudak and the Jalta areas, samples of microframeworks with Crescentiella originated from both the lower and rarely the central parts of the reef complexes. In the upper part of the reef successions, Crescentiella is less common, patchily distributed and does not form any microframeworks. In the Sudak area, observations were made in the following localities: the Koba-Kaya Mts., (N4449'22"; E34 $55^{\prime} 00^{\prime \prime}$; Fig. 2a),

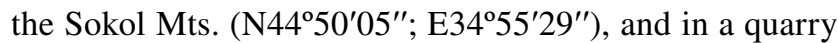

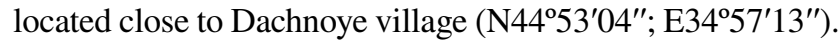
In the Jalta area, studies were carried out in the steep part of
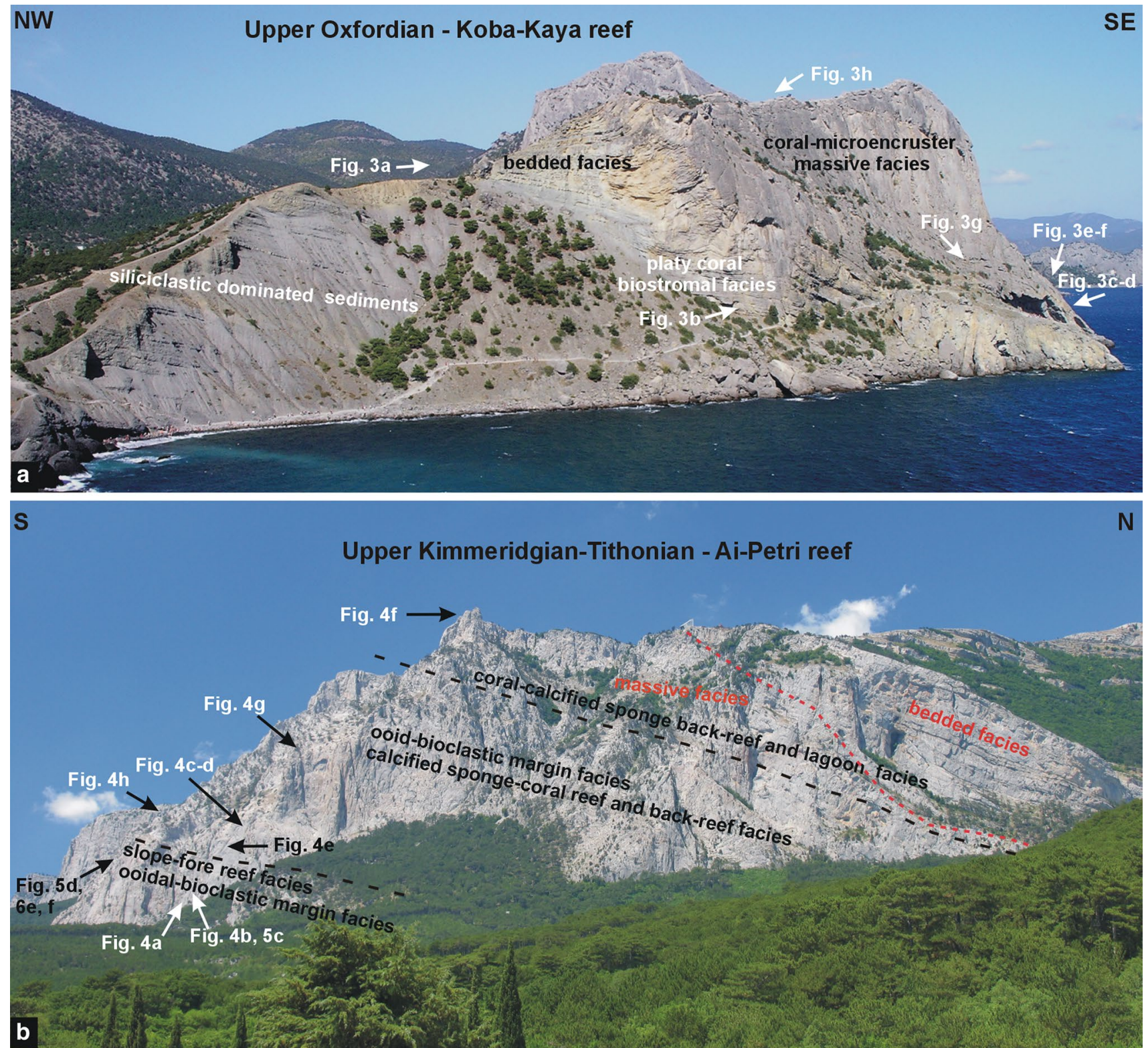

Fig. 2 Examples of the Upper Jurassic reefs of Crimea. Arrows indicate the approximate position of examples presented in Figs. 3, 4, 5, 6, 7. a Sudak area (Novyi Svet); Upper Oxfordian Koba-Kaya Mts (altitude: $165 \mathrm{~m}$ ) reef, which is mainly composed of platy coral facies and coral-microencruster facies; laterally massive facies pass into bedded facies and siliciclastic-dominated sediments. Rock walls are up to $140 \mathrm{~m}$ high. b Jalta area; Upper Kimmeridgian-Tithonian AiPetri Mts (altitude: $1234 \mathrm{~m}$ ), which are mainly composed of calcified sponge-coral, ooidal-bioclastic and coral-calcified sponge facies; the general trend in reef succession has been marked. For detailed logs see Krajewski $(2008,2010)$. Rock walls are up to $600 \mathrm{~m}$ high 
the Ai-Petri Massif (N4426'33"; E34'02'58'; KB, KC sections in Krajewski 2008; Bucur et al. 2014; Fig. 2b).

The main research method was macroscopic observations, microfacies analysis and cathodoluminescence (CL) microscopy. CL observations were carried out using a cold-stage cathodoluminescence microscope CLmk3 A of CIT Ltd., coupled to the Nikon Eclipse $50 \mathrm{~T}$. The accelerating voltage was $15-17 \mathrm{kV}$ and the electron-beam intensity $450-500 \mu \mathrm{A}$. Earlier field studies regarding full reef succession enabled the first author to collect 1047 representative samples for microfacies (e.g., Krajewski and Olszewska 2006; Krajewski 2008, 2010; Bucur et al. 2014). The thin sections marked with numbers indicated in Figs. 3, 4, 5, 6 and 7 are stored at the Faculty of Geology, Geophysics and Environment Protection, AGH University of Science and Technology in Kraków, Poland (M. Krajewski’s Crimea Collection).

\section{Results}

\section{Field occurrence of the Crescentiella-microbial-cement $(\mathrm{Cmc})$ microframeworks}

\section{Sudak area (Upper Oxfordian reefs)}

In the Sudak area, investigations were carried out in the KobaKaya Mts., the Sokol Mts. and in the quarry close to Dachnoye village (Figs. 2a, 3). The sediments encountered there represent the Upper Oxfordian massive and bedded facies (e.g., Muratov 1973; Nikishin et al. 2015b; Figs. 2a, 3a). The bedded, partly marly facies is formed by coral floatstones with platy microsolenids whereas the massive facies is dominated by coral-microencruster boundstones (Fig. 3; Nikishin et al. 2015b). In the lower parts of the reefs and down the reef slope, both platy microsolenids and Actinaraea occurred (Fig. 3b). Both nodular and massive colonies coexisted with branching and dendroid corals (Fig. 3e-g). In a significant number of the reefs, branching scleractinians occur. Among the corals forms such as Calamophylliopsis, Stylosmilia, Thecosmilia, and Heliocoenia were identified. In the reef slope, coral-bioclastic grainstones-rudstones accumulated (Fig. 3c, d). In the massive facies, growth cavities with geopetal infillings were seen, indicating that the KobaKaya and the Sokol reefs have not been tectonically tilted. In the uppermost part of the reefs, synsedimentary breccias and microbial laminites have been observed (e.g., in the Koba-Kaya Mts.; Fig. 3h). Similar observations in the nearby Oxfordian reef (Sudak fortress mountain) were carried out by Geister et al. (2007). In a brief description, they distinguished a barrier reef system with lateral coral facies change from back-reef over the reef crest with dominating upright branching scleractinians to a steep reef slope with increasing presence of platy corals (Geister et al. 2007).
In the lower parts of the reef successions, bioclastic wackestones and coral floatstones are prevailing. Higher in the sequence, massive gray limestones appear classified as bioclastic grainstone-rudstones with Crescentiella as well as Crescentiella-microbial-cement $(\mathrm{Cmc})$ boundstones (Fig. 5a, d). Both the lateral and vertical ranges of the $\mathrm{Cmc}$ boundstones are difficult to estimate due to the steepness of the terrain. In the best-accessible, lower part of the quarry near Dachnoye village (Fig. 5a), the $\mathrm{Cmc}$ lateral extension is up to several meters and the vertical one is about $1.5 \mathrm{~m}$. Up the sequence, the facies with numerous Crescentiella grades into coral boundstones-floatstones (Fig. 5a, b). The contact between Crescentiella-microbial facies and coral facies is sharp.

\section{Jalta area (Upper Kimmeridgian-Tithonian reef)}

The Ai-Petri reef complex comprises strongly lithified, gray, massive Stramberk-type reef facies grading laterally into thick- and thin-bedded facies (Fig. 2b) with some intervals of mixed, siliciclastic-carbonate facies in both the lower and its central parts (Krajewski 2008, 2010). Based on biostratigraphic analyses the massive facies of the Ai-Petri reef is Upper Kimmeridgian-Tithonian in age whereas the bedded facies encountered in the uppermost part of the reef (Fig. 2b) is of Lower Berriasian age (Krajewski and Olszewska 2006, 2007). Generally, several main intervals are observed in which the slope and the fore-reef, marginal, back reef, and lagoonal facies are evident, all reflecting the reef evolution (Fig. 2b). Moreover, several smaller, repeating, low-rank sedimentary sequences can be observed (Krajewski 2008, 2010).

The lower part of reef complex in question comprises mainly bioclastic wackestones, platy corals floatstones with microsolenids and microbial boundstones, several tens of meters in thickness (Fig. 4a, b). Up the sequence, the fossil assemblage reveals a high diversity with dasycladalean and udoteacean algae (Fig. 4g), foraminifers, calcified demosponges (stromatoporoids and chaetetids, e.g., Chaetetopsis spengleri, Pseudoseptifer, Actinostromaria, Milleporidium, Sarmentofascis? digitatus, Cladocoropsis, Stromatopora, Milleporella; Fig. 4c, d), corals (e.g., Stylina, Thecosmilia, Heliocoenia, Latomeandra, Stylosmilia; Fig. 4e, f) and a wide spectrum of microencrusters including Crescentiella morronensis, Pseudolithocodium carpathicum, Koskinobullina socialis, Thaumatoporella parvovesiculifera, Lithocodium aggregatum. In the middle part of this sequence, bioclastic-ooidal marginal facies sometimes prevails over the reef facies (Fig. 4h). The boundstones and floatstones are built mainly by calcareous sponges and corals skeletons. Densely packed skeletons reveal growth with microencrusters and microbialites representing secondary reef-builders. Both the sponge and the sponge-coral facies are observed especially in 

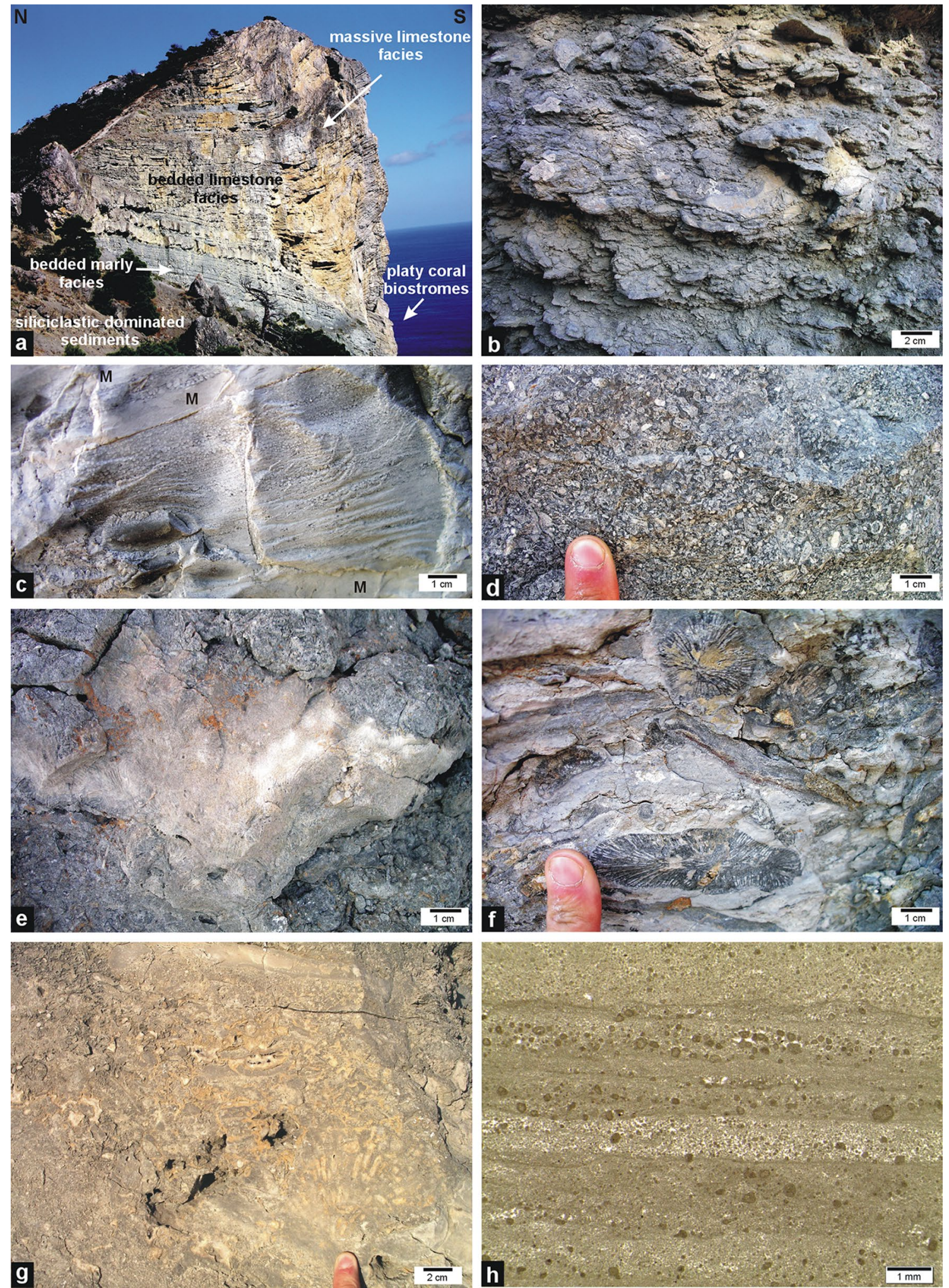

Fig. 3 Examples of Oxfordian reef facies from Sudak area. a KobaKaya reef; western slope, in the lower part bedded marly facies with platy coral; in the upper part transition zone from massive coralmicroencruster facies to bedded bioclastic facies. The rock wall is up to $50 \mathrm{~m}$ high. b Platy coral biostrome observed in the lower part of the reefs. c Reef slope facies with reef detritus and microbialites (M). d Reef slope with coral and bioclast detritus. e-g Coral-microencruster massive reef facies. $\mathbf{h}$ Microbial laminites from the highest part of the Koba-Kaya reef; sample Kob 2. Location of the examples is presented in Fig. $2 \mathrm{a}$ 

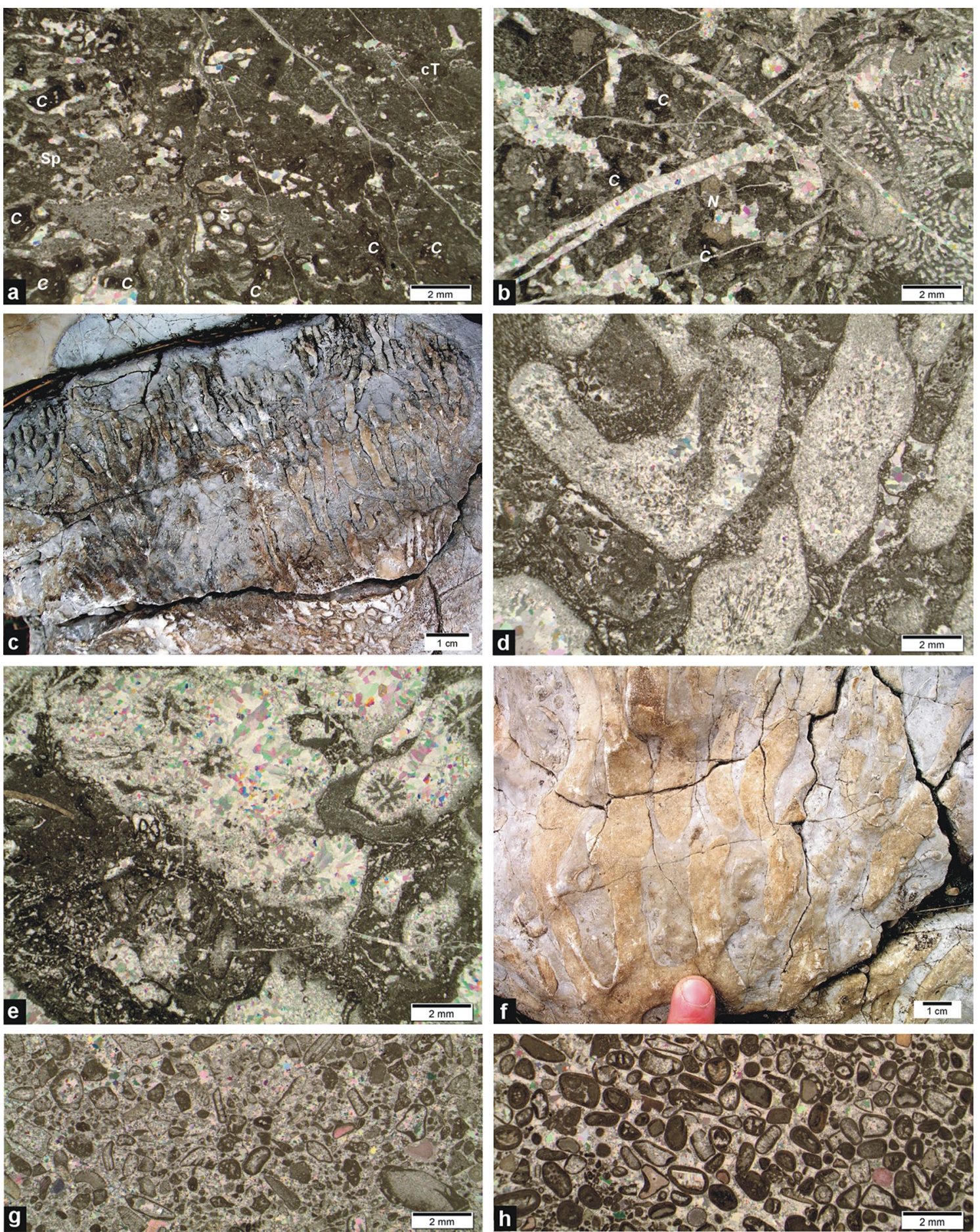

Fig. 4 Examples of the Upper Kimmeridgian-Tithonian reef facies from Jalta area. a Microbial boundstone; $S p$ sponge, $S$ serpulids, $C$ Crescentiella, $c T$ clotted thrombolite; lower part of the Ai-Petri reef; sample KB 7g. b Microsolena-thrombolite boundstone; $C$ Crescentiella; N Neuropora; lower part of the Ai-Petri reef; sample KB 36d. c Weathered rock surface showing calcareous sponge skeletons of Sarmentofascis? digitatus Schlagintweit \& Krajewski mostly longi-

tudinal-oblique sections. d Sponge-microencruster boundstone; sample KB 51a. e Coral-microencruster boundstone; fragment of Heliocoenia $\mathrm{cf}$. variabilis colony; sample KB 41c. f Coral floatstone; upper most part of the Ai-Petri reef. $\mathbf{g}$ Bioclastic grainstone with fragments of calcareous green algae; sample KB $6 \mathrm{c}$. h Ooid-cortoid grainstone; sample KC 19c. Location of the examples is presented in Fig. 2b 

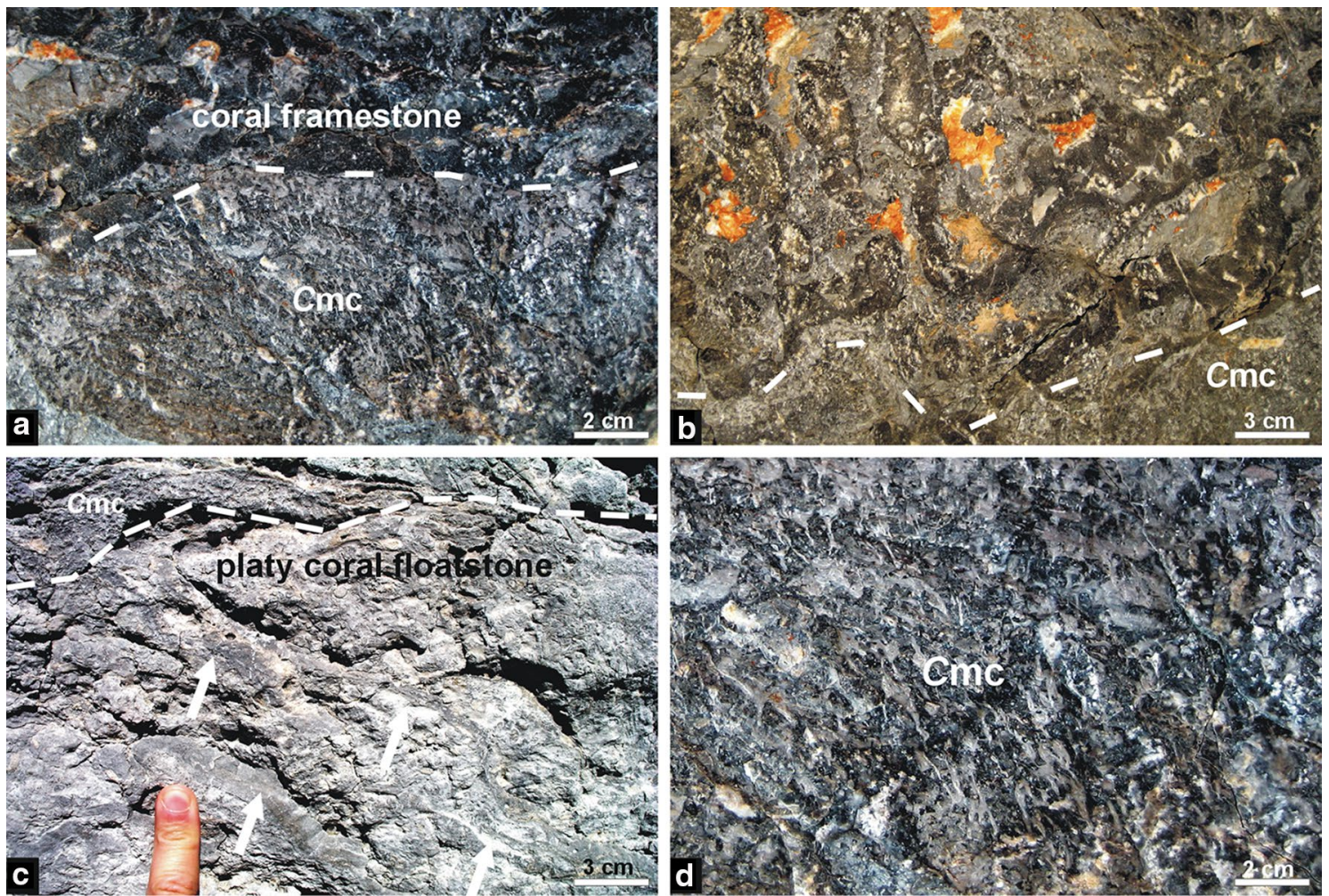

Fig. 5 Field views of the Crescentiella-microbial-cement microframeworks in the Upper Jurassic reefs of Crimea. a, b Upper part of the Crescentiella-microbial-cement microframework $(\mathrm{Cmc})$ succession; in the lower part $C \mathrm{mc}$ microframework; in the upper part coral framestone; the boundary is sharp and undulated; Dachnoye quarry. c Lower part of the Crescentiella-microbial-cement microframework
$(C \mathrm{mc})$ succession; in the lower part platy coral (arrows) biostrome; in the upper part $C \mathrm{mc}$ microframework; Ai-Petri Mts. d Crescentiellamicrobial-cement microframework $(\mathrm{Cmc})$; densely packed aggregates of branching individuals of Crescentiella; numerous voids (white or yellow parts) are filled with early and late cements; Dachnoye quarry the lower and the middle parts of the reef sequence whereas the coral-sponge facies is more common in its uppermost part.

The sedimentary sequence with the $\mathrm{Cmc}$ microframework was observed in the lower portions of the Ai-Petri reef succession (Figs. 2b, 5c) and, less commonly, in its middle portion (Krajewski 2010). In the upper reef succession, Crescentiella occurs dispersed in the peri-reefal bioclastic wackestones-floatstones or growing on skeletons of sponges and corals. The lower reef succession is dominated by bioclastic wackestones and coral floatstones followed upward by microbial, Crescentiella-microbial and calcified spongecoral facies. The $\mathrm{Cmc}$ microframeworks of meter-scale lateral, and decimeter-scale vertical extensions were noticed although it is difficult to estimate their true lateral extent due to the steepness of the terrain.

\section{Microfacies of the Crescentiella-microbial-cement (Cmc) microframework}

Generally, in both the Upper Oxfordian and the Upper Kimmeridgian-Tithonian reefs from the Crimea area, the macroscopic features of the $\mathrm{Cmc}$ microframeworks are similar (Figs. 5, 6, 7, Table. 1): both are dark-grey (Sudak area) or light-grey (Jalta area), hard, lithified limestones (Fig. 5a-d). The sediment consists of densely packed Crescentiella, mostly in growth position (Figs. 5a, d, 6e, f). Common are caverns filled with various generations of cements, some of them representing stromatactis-like caverns with geopetal infillings (Fig. 6e). The microframeworks are dominated by Crescentiella accompanied by microbialites and specimens of the branching sclerosponge Neuropora lusitanica Termier (Fig. 6a, b). Some specimens of Crescentiella morronensis are up to $1.3 \mathrm{~cm}$ in height. Within the Crescentiella laminae, foraminifers and fine bioclasts are observed. Crescentiella is formed by encrustation or symbiosis between nubecularid foraminifers (Figs. 6e, f, 7a) or enigmatic, spar-filled, tubeshaped structures (Fig. 6a-d) and the microbial envelopes (Senowbari-Daryan et al. 2008; Schlagintweit and Gawlick 2009; Pleş et al. 2017). The basic difference between the Upper Oxfordian and the Upper Kimmeridgian-Tithonian specimens is the variable amount of nubecularid foraminifera and tube-shaped structures forming the central cavities 

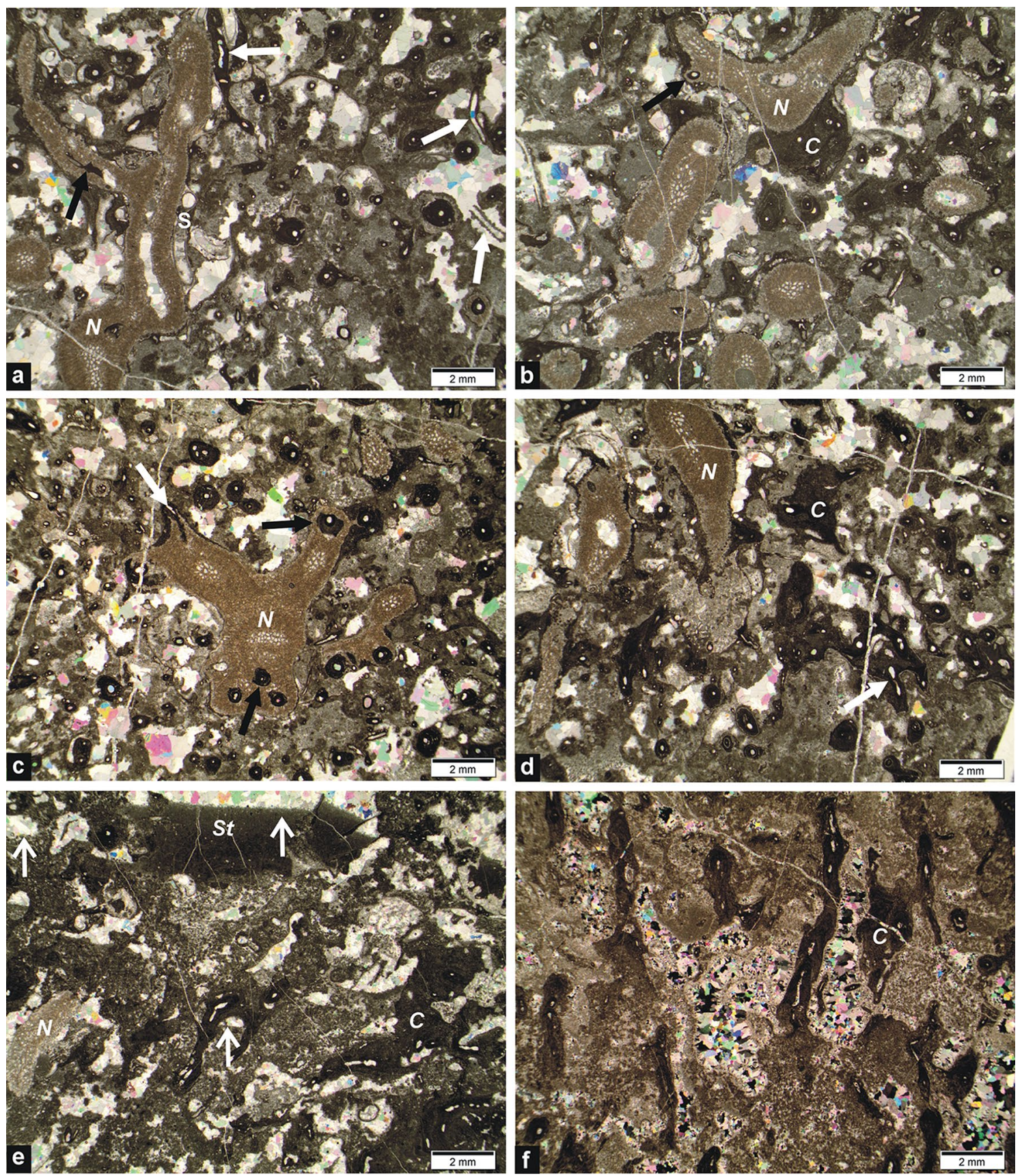

Fig. 6 Crescentiella-microbial-cement microframeworks. a-d Crescentiella-microbial boundstone; numerous longitudinal and transverse sections of Crescentiella and branches of Neuropora with serpulid encrustations; some specimens of Crescentiella $(C)$ overgrow Neuropora $(N)$ or filled borings (black arrows); Crescentiella is formed mostly by enigmatic tube-shaped structures (white arrows) and microbial envelopes; Sudak area, samples D2b, D2c, D2d. e Crescentiella-microbial boundstone; in the left lower part Neuropora $(N)$;

of Crescentiella. In the Upper Oxfordian samples, higher amounts of tube-shaped, enigmatic structures are observed whereas in the Upper Kimmeridgian-Tithonian specimens, nubecularid foraminifers prevail. in the upper part stromatactis-like cavity $(S t)$, growth cavities and borings with geopetal infillings (white arrows); Crescentiella $(C)$ is formed mostly by nubecularid foraminifers and microbial envelopes; Jalta area; sample KC7c. f Crescentiella-microbial boundstone; microframework created by Crescentiella $(C)$; voids filled with multiple cement generations (for details see Fig. 7; Ai-Petri reef; sample $\mathrm{KC} 7 \mathrm{~b}$

In both areas, Crescentiella is commonly accompanied by the branching sclerosponge Neuropora, more common in the Oxfordian reefs from the Sudak area (Fig. 6a-d). Usually, specimens of Neuropora grow vertically as delicate, 

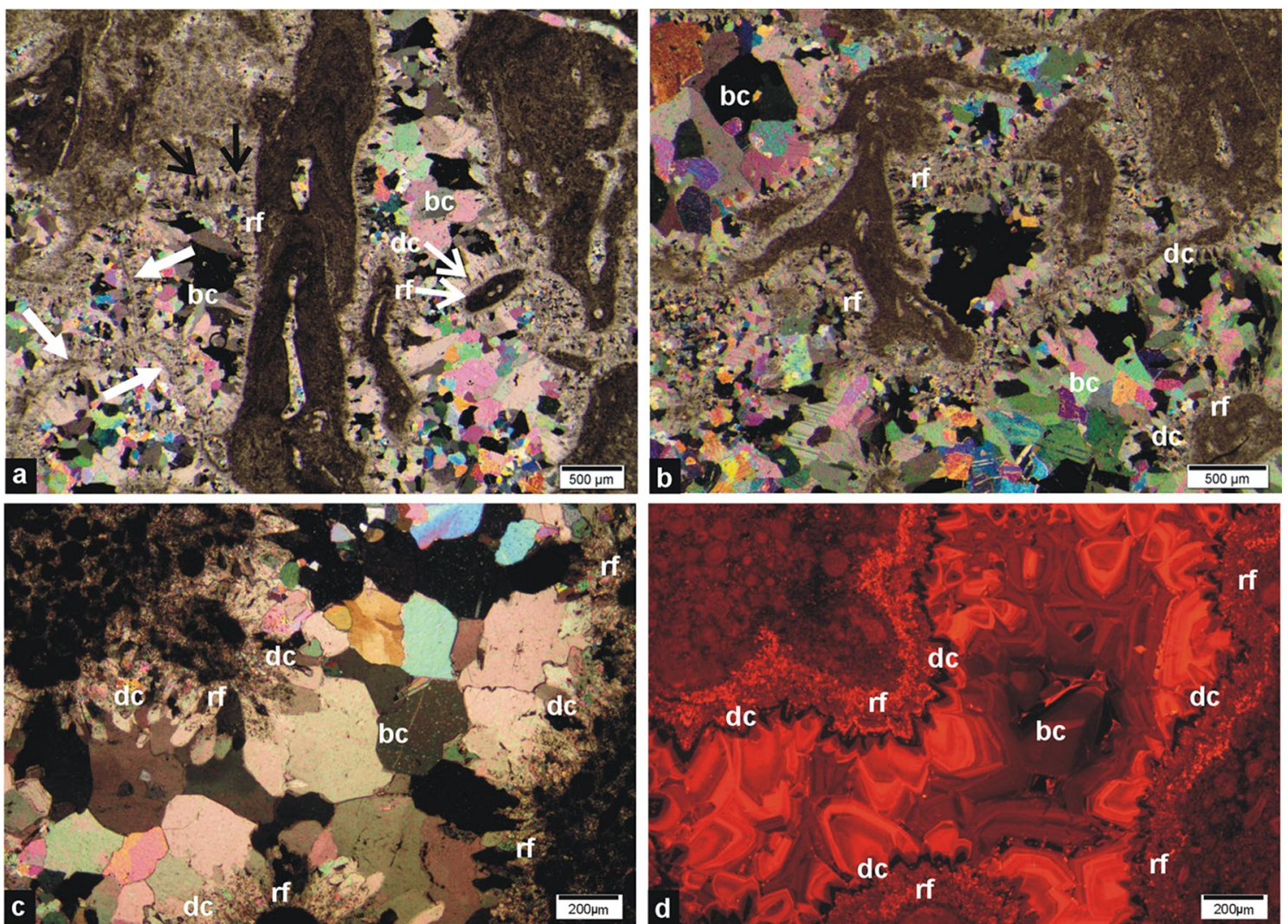

Fig. 7 Crescentiella-microbial-cement microframeworks. a, b Crescentiella-microbial-cement microframeworks; multiple cement generations are visible; the first generation of cement is represented by a fine rim of radiaxial-fibrous cement (rf) surrounding Crescentiella and voids followed by dog tooth spar (dc) and a final generation of blocky cement (bc). Sometimes the morphology of the cements resembles splay or botroid fabrics (black arrows); in voids, thin micritic films are visible; on micritic films fibrous cement is devel-

ramified colonies with branches ranging from 2 to $5 \mathrm{~mm}$ in diameter and showing dendroidal forms (Fig. 6a). In many cases, Crescentiella was growing on Neuropora specimens thereby connecting the branches (Fig. 6a, b). Similar to bryozoans and serpulids, Neuropora prefers cryptic habitats and is regarded as frame encruster (Fürsich and Werner 1991).

Further important components are microbialites, which form clotted fine, peloidal fabrics between the Crescentiella colonies (Fig. 6a-f). Sometimes, faint layered structures can be observed. In the voids, thin micrite films onto which thin, fibrous cement crusts grow can be observed (Fig. 7a).

Among the biogenic components, bryozoans and serpulids occur, developed mostly on sponges (Fig. 7a) and encrusting foraminifers (e.g., Nubeculariidae) together with numerous, enigmatic, irregular, polymorphous, spar-filled, tube-like microfossils resembling some taxa of mutualistic

oped (white arrows); sample KC7b. c, d crossed nicols (c) and CL image (d) of the void filled with different generation of cements in the microframework and chronological order of cementation is highlighted by cathodoluminescence; radiaxial-fibrous cement (rf) is covered with non-luminescent, marine, phreatic dog tooth cement (dc), which shows red luminescence only in the outer zones of crystals; the center of the void is filled with blocky cement (bc); sample KC7e

sponge-epibiont consortia (Schlagintweit and Gawlick 2009).

Numerous voids show the irregular shapes of inorganic origin (growth-framework porosity) or the oval shapes of possible organic provenance (biomoulds; Fig. 6a-f). In the caverns, faint relics of dissolved sclerosponges can be observed displaying poorly preserved internal structures (Fig. 6a, b). In the microframework, stromatactis-like cavities (sensu Matyszkiewicz 1997) are common (Figs. 5d, 6e). Cavities reach $3 \mathrm{~cm}$ in length and are up to $1.5 \mathrm{~cm}$ high. In their basal parts, the cavities contain internal sediments, followed by calcite cement. Internal sediment is represented by mudstone-thin bioclastic wackestone.

Although the Crimean Late Jurassic reefs are mostly organic reefs, it must be noticed that the $\mathrm{Cmc}$ microframeworks are also composed of various cements, which may constitute up to $30 \%$ of its components. The radiaxial fibrous cements represent the first generation of cements which developed as thin layers on the walls of voids (Fig. 7a-d), on 
Table 1 Characteristics of the Crescentiella-microbial-cement microframeworks in the Upper Jurassic reefs of the Crimean Peninsula. Reef classification after Riding (2002)

\begin{tabular}{|c|c|c|}
\hline Location & Sudak area & Jalta area \\
\hline Age & Upper Oxfordian & Upper Kimmeridgian-Lower Berriasian \\
\hline \multirow[t]{2}{*}{ Type of bioconstruction } & $\begin{array}{l}\text { Mainly: Coral biostrome, coral-microencruster cluster, seg- } \\
\text { ment and frame reef }\end{array}$ & $\begin{array}{l}\text { Mainly: Calcified sponge-coral-microencruster seg- } \\
\text { ment and frame reef, coral biostrome }\end{array}$ \\
\hline & Locally: Skeleton-cement and microbial reef & Locally: Skeleton-cement and microbial reef \\
\hline $\begin{array}{l}\text { Crescentiella-microbial- } \\
\text { cement microframework }\end{array}$ & Present & Present \\
\hline Position in the sequence & $\begin{array}{l}\text { Lower part of the sequence; between platy } \\
\text { mainly microsolenid biostromes and coral microencruster } \\
\text { reefs }\end{array}$ & $\begin{array}{l}\text { Mainly lower part of the sequence between } \\
\text { microbial reefs, microsolenid biostromes and } \\
\text { stromatoporoid-coral-microencruster reef and } \\
\text { ooid facies }\end{array}$ \\
\hline Main components & $\begin{array}{l}\text { Crescentiella, Neuropora, microbialites } \\
\text { cements, serpulids, foraminifers }\end{array}$ & $\begin{array}{l}\text { Crescentiella, Neuropora, microbialites, } \\
\text { cements, serpulids, foraminifers }\end{array}$ \\
\hline Crescentiella & $\begin{array}{l}\text { Central cavities: mainly enigmatic tube-shaped } \\
\text { structures, rarely nubecularid foraminifers; } \\
\text { microbial envelopes }\end{array}$ & $\begin{array}{l}\text { Central cavities: mainly nubecularid } \\
\text { foraminifers, rarely enigmatic tube-shaped } \\
\text { structures; microbial envelopes }\end{array}$ \\
\hline Cement content & Moderate & Moderate, locally high dominating \\
\hline Cements & Radiaxial-fibrous, blocky & $\begin{array}{l}\text { Isopachous, radiaxial-fibrous, dog tooth } \\
\text { microcrystalline, blocky }\end{array}$ \\
\hline Microfacies & Crescentiella-microbial-cement boundstone & Crescentiella-microbial-cement boundstone \\
\hline Size & dm-scale thickness m-scale or more extent & dm-scale thickness m-scale or more extent \\
\hline Structure & $\begin{array}{l}\text { Densely packed Crescentiella with stromatactis-like } \\
\text { cavities }\end{array}$ & $\begin{array}{l}\text { Densely packed Crescentiella with stromatactis-like } \\
\text { cavities }\end{array}$ \\
\hline Facies interpretation & Forereefal to upper slope & Upper slope to marginal setting \\
\hline
\end{tabular}

Crescentiella specimens (Fig. 7a) as well as on thin, micrite films cutting through the voids (Fig. 7a). Important infillings of the voids are represented by massive, radiaxial fibrous and dog tooth cements (Fig. 7a). The central parts of the voids are filled with blocky cement type.

\section{Micropaleontology \\ of the Crescentiella-microbial-cement $(\mathrm{Cmc})$ microframework}

\section{Microencrusters}

Genus Crescentiella Senowbari-Daryan et al. 2008.

\section{Crescentiella morronensis (Crescenti 1969) Figs. 5, 6, 7}

Remarks: For a detailed description and interpretation see Senowbari-Daryan et al. (2008). We may note here that in the same year when Crescenti described Tubiphytes morronensis from the Late Jurassic of Italy, this microorganism was also described by Dragastan (1969) neutrally as "microoncolites" from the Late Jurassic of Romania, but without application of Linnean nomenclature. Subparallel growing, transversely sectioned specimens of $C$. morronensis might refer to a taxon described by Dragastan (2010), pl. 78A recently as Sarsteinia getica (interpreted as a sponge) from the late Tithonian of the Getic Carbonate Platform of Romania. In the material from the Crimea, the elongated specimens attain a length of up to $8 \mathrm{~mm}$ and a thickness of up to $1.5 \mathrm{~mm}$ (mostly $0.8-1.0 \mathrm{~mm}$ ). The internal sparite-filled cavity (or core) maybe either a cylindrical tube of unknown systematic position or a foraminifera (Nodopththalmidium, Nubeculinella) with superimposed amphora-like chambers (Figs. 6, 7a). Most of the Crimean forms belong to the gregarious $C$. morronensis forma colligaris morphotype with laterally connected laminated crusts as described by Senowbari-Daryan et al. (2008). In some cases, depending on the plane of sectioning, the differentiation of the two morphotypes (forma morronensis and forma colligaris) may be difficult if not impossible. This peculiar morphotype was described by (Dragastan 1969, Fig. 1, right side) as "microoncolithe, sous-type amalgam". Individual specimens are observed filling borings affecting the skeletons of Neuropora (Fig. 6c). As Crescentiella has never been reported exhibiting an euendolithic potential, these borings were drilled by other organisms of unknown taxonomic origin. These specimens nicely show the inner microbial crust layer of the cortex to be denser and therefore darker (Fig. 6a, c).

\section{Sclerosponges}

Genus Neuropora Bronn, 1825. Neuropora lusitanica Termier, 1985 (Fig. 6a-e) 
Remarks: Termier in Termier et al. (1985) distinguished two morphotypes of $N$. lusitanica (Oxfordian of Portugal), encrusting and ramose (tree-like branching). The Crimean specimens belong to the ramose morphotype forming delicate, branched colonies with branches ranging from 2 to $5 \mathrm{~mm}$ in diameter. As already mentioned, many skeletons display macroborings that are often completely filled with Crescentiella specimens (Fig. 6c). It is worth mentioning that long time considered a bryozoan, the sclerosponge nature of Neuropora Roemer was evidenced by Kaźmierczak and Hillmer (1974).

\section{Discussion}

In the evolution of Jurassic platform of the Crimea Peninsula, the $C \mathrm{mc}$ microframework was observed at two main stages of carbonate platform evolution, separated by erosional unconformity and stratigraphic gap (Nikishin et al. 2015b, cf. Baraboshkin and Piskunov 2010; Fig. 1, Table 1). Deposits of the first stage can be observed in the eastern part of Crimea Mts. (Sudak area) while the deposits of the second stage occur in the central and western parts (Jalta area). In the Middle-Late Oxfordian succession which represents the first stage of carbonate platform evolution, the $\mathrm{Cmc}$ microframeworks represent the initial evolution of the Sudak Series reefs. The $\mathrm{Cmc}$ microframework with stromatactislike occur in the transitional phase, from relatively deep water bioclastic and platy coral facies (some tens of meters, e.g., Leinfelder et al. 1996; Insalaco et al. 1997; Lathuilière et al. 2005) to shallow subtidal coral-microencruster facies. The latter is dominated by massive and branching corals building the main parts of the reefs.

In the Late Kimmeridgian-Tithonian, which represents the second stage of carbonate platform evolution, represented in the Yaila Series (Fig. 1), the development of $\mathrm{Cmc}$ microframeworks was related to the consecutive stages of reef growth. The Upper Oxfordian-Early Kimmeridgian depositional break caused by tectonic movements was followed by the gradual restoration of reef communities. The bioclastic wackestones-floatstones and platy coral-microbial boundstones-floatstones located in the lower part of reef succession can be linked to the platform slope facies (Krajewski 2008, 2010). Up the sequence, the reefs structures evolved into meter-scale, low-relief microbial reefs with $\mathrm{Cmc}$ microframework, and stromatactis-like caverns. Higher up the reef succession is dominated by shallow subtidal massive sponge and coral boundstone or marginal oolitic facies (Krajewski 2008, 2010).

At both large-scale phases of reef development, the microbial and the $\mathrm{Cmc}$ boundstones contributed to the stabilization of loose substrate, which enabled the vigorous growth of calcified sponges and corals constituting the main parts of the reefs, together with common microencrusters such as Lithocodium, Thaumatoporella etc. Hence, the described $C \mathrm{mc}$ microframeworks from the Sudak and the Jalta areas represent the initial stages of long cycles of restoration and blooming of the reefs in the Middle-Late Oxfordian and in the Late Kimmeridgian-Tithonian. The main phase of reef growth was characterized by vigorous expansion of a wide spectrum of massive and branching skeletal metazoans and microencrusters building the Frame Reef sensu Riding (2002).

Although the $\mathrm{Cmc}$ microframeworks were mostly observed in the lower parts of the reef successions, their infrequent presence must be mentioned also in the middle parts of the reef successions of the Ai-Petri massif where they were accompanied by minor metazoans. In the AiPetri reef, the repeating, vertical facies changes represent lower-rank cycles (Krajewski 2008, 2010). The appearance of microbial and $\mathrm{Cmc}$ microframeworks together with the deficit of main reef builders can be explained by a crisis in metazoans growth caused by paleoenvironmental stress then followed by the flourishing sponge-coral-microencruster communities. Similar to recent reefs, the Late Jurassic reefs were very sensitive to environmental changes (sea level fluctuations, tectonic events, climate, nutrient content, temperature, etc.). In the Ai-Petri reef, periods were documented during which carbonate production was disturbed by the influx of siliciclastic material and nutrients (Krajewski 2008, 2010; KB and KC sections). Such episodes, triggered by tectonic activity in the surrounding areas, resulted in periodical breaks in the reef growth. However, after the crisis, the restoration of reefs took place, as indicated by deposition of detrital bioclastic wackestones-floatstones followed by microbial and $\mathrm{Cmc}$ boundstones and, finally, succeeded by sponge-coral-microencruster framestones showing high biodiversity. In both the high and low sedimentary cycles of the Crimean reefs, the $\mathrm{Cmc}$ microframework also appears at the initial phase of reef growth after the breaks in metazoans development, during the restoration of the reef fauna assemblages.

The $C \mathrm{mc}$ microframestone formed under phreatic conditions, in the upper slope, fore-reef and seaward marginal depositional settings where intensive synsedimentary cementation took place. Such environments are characterized by marginal topography and intensive fluid flow (e.g., Della Porta et al. 2003; Flügel 2004; Seeling et al. 2005; Marangon et al. 2011). Both Crescentiella and the microbialites were not only able to adapt to unstable environmental conditions but also stabilized the sediments, thus supporting the development of skeletal metazoans building the main parts of reef complexes. Significant contents of early cement crusts are typical of reefs showing low sedimentation rates and higher rates of water agitation, i.e., conditions preferred by low-growing microbialites and Crescentiella. 
These cements formed prior to burial, when the voids were open for the early cementation formed marine phreatic conditions. The synsedimentary origin of the fibrous cement is evidenced by microencrusters overgrowth (cf. Kendall and Tucker 1973; Koch and Schorr 1986; Flügel 2004; Schlagintweit and Gawlick 2008). The presence of thin micritic films in cavities intercalating various cement generations indicates that the early marine cementation took place when the voids were opened to marine water (e.g., Payne et al. 2006). In the massive reef sediments, the burial diagenesis is represented by blocky cement constituting the latest cement generation (e.g., Koch and Schorr 1986; Flügel 2004). In the Sudak reefs, large crystals of blocky cement partly replaced the earlier, fibrous cements as a result of burial/meteoric solution. In the Ai-Petri reef, the generations of cements are well preserved. The reefal limestones rich in microbialites and cements are typical of steep, high-energy upper slope depositional setting (e.g., Della Porta et al. 2003, 2013; Flügel 2004; Marangon et al. 2011). The lack of dasycladacean algae and typical shallow water microproblematica (e.g., Lithocodium, bacinellid fabrics, Thaumatoporella etc.) described from higher part of the Crimean reefs (Krajewski 2008; Baraboshkin and Piskunov 2010; Piskunov et al. 2012; Bucur et al. 2014) suggest that the $\mathrm{Cmc}$ microframework is rather deeper than several meters.

The examples of $\mathrm{Cmc}$ microframework encountered in the Crimea Mts., formed by small, low-growing Crescentiella and microbialites, and rich in early cement crusts resemble Permian algae-microbial-cement reefs (e.g., Edwards and Riding 1991; Flügel 1994; Saller et al. 1999; Wood 1999; Weidlich 2002; Schlagintweit and Gawlick 2008; Kosakowski and Krajewski 2014) as well as Triassic Tubiphytes and cement crust-dominated reefs (Senowbari-Daryan et al. 1993; Flügel 2002; Schlagintweit and Gawlick 2008; Marangon et al. 2011; Senowbari-Daryan 2013; Popa et al. 2014).

\section{Conclusions}

1. In the lower, rarely in the middle part of the Upper Jurassic reef successions of the Crimean Peninsula Crescentiella morronensis, microbialites and cements form cement-supported reefs. Although the Crimean Late Jurassic reefs are mostly organic reefs, it must be noticed that the Crescentiella-microbial-cement microframeworks are also composed of multiple generations of early and late cements, which may constitute up to $30 \%$ of its volume. Such structures have so far not been described in detail from the Crimea-Caucasus region.
2. In the evolution of Jurassic carbonate platforms of the Crimea Peninsula, the Crescentiella-microbial-cement microframeworks were observed in two main stages of carbonate platform evolution. Generally, in both the Middle-Upper Oxfordian and the Upper Kimmeridgian-Tithonian phases of Crimean reefs development, the features of the Crescentiella-microbial-cement microframeworks are similar. They consist of densely packed Crescentiella accompanied by microbialites and branched colonies of Neuropora lusitanica. The main difference between the Middle-Upper Oxfordian and the Upper Kimmeridgian-Tithonian specimens is the variable amount of nubecularid foraminifera and tube-shaped structures forming the central cavities of Crescentiella.

3 . In the Middle-Late Oxfordian reef successions exemplified in the Sudak area, the metric-scale Crescentiella-microbial-cement microframeworks occur in the transitional realm from relatively deep water bioclastic and platy coral facies to shallow subtidal massive and branching corals facies. The Upper Oxfordian-Early Kimmeridgian depositional break was followed by the gradual restoration of reef communities. In the Late Kimmeridgian-Tithonian which represents the second stage of carbonate platform evolution, exemplified in the Jalta area, the development of Crescentiella-microbialcement microframeworks was related to the consecutive stage of reef growth. The relatively deep water mainly microsolenid facies, up the sequence of the reefs structures evolved into meter-scale, low-relief cement-supported reefs with Crescentiella-microbial-cement microframework. Higher up, the reef succession is dominated by shallow subtidal Štramberk-type massive calcified sponge and coral boundstone and oolitic facies. Hence, the described Crescentiella-microbial-cement microframeworks from the Sudak and the Jalta areas can be observed in the initial stages of long cycles of restoration and blooming of the reefs in the Middle-Late Oxfordian and in the Late Kimmeridgian-Tithonian.

4. The Crescentiella-microbial-cement microframestone in the Crimean reefs formed under phreatic conditions, in the upper slope and seaward marginal depositional settings where intensive synsedimentary cementation took place. Both the Crescentiella and the microbialites were not only able to adapt to unstable environmental conditions but also stabilized the sediments, thus supporting the development of skeletal metazoans building the main parts of reef complexes. Significant contents of early cement crusts are typical of reefs showing low sedimentation rates and higher rates of water agitation, i.e., conditions preferred by low-growing microbialites and Crescentiella. 
Acknowledgements The authors are grateful to the two reviewers, G. Pleş and Anonymous, as well as the editor A. Munnecke for their constructive comments and suggestions that considerably improved this paper. MK would like to thank L. Guo and S.J. Vincent for useful discussions. The research was financed from the AGH-UST Grant Nos. 11.11.140.626.

Open Access This article is distributed under the terms of the Creative Commons Attribution 4.0 International License (http://creativeco mmons.org/licenses/by/4.0/), which permits unrestricted use, distribution, and reproduction in any medium, provided you give appropriate credit to the original author(s) and the source, provide a link to the Creative Commons license, and indicate if changes were made.

\section{References}

Afanasenkov AP, Nikishin AM, Obukhov AN (2005) The system of Late Jurassic carbonate buildups in the northern Shatsky swell (Black Sea). Dokl Earth Sci 403:696-699

Arkadiev V, Guzhikov A, Baraboshkin E, Savelieva J, Feodorova A, Shurekova O, Platonov E, Manikin A (2018) Biostratigraphy and magnetostratigraphy of the upper Tithonian-Berriasian of the Crimean Mountains. Cretac Res 87:5-41

Baraboshkin EYu, Piskunov VK (2010) The structure and formation conditions of the Upper Jurassic succession in the area of Mount Pakhkal-Kaya (Crimea). Mosc Univ Geol Bull 65:17-26

Bendukidze NS (1982) Late Jurassic corals from deposits of reefal origin from the Caucasus and Crimea. Geological Institute A.I. Dzhanelidze, Academy of Sciences of Georgian SSR, Trudy (n.s.) 74:3-166 (in Russian)

Bucur II, Săsăran E (2005) Micropaleontological assemblages from the Upper Jurassic-Lower Cretaceous deposits of Trascău Mountains and their biostratigraphic significance. Acta Paleont Rom 5:27-38

Bucur II, Granier B, Krajewski M (2014) Calcareous algae, microbial structures and microproblematica from Upper Jurassic-lowermost Cretaceous limestones of southern Crimea. Acta Palaeont Rom 10:61-86

Crescenti U (1969) Biostratigrafia delle facies Mesozoiche dell'Appennino Centrale: correlazioni. Geol Romana 8:15-40

Della Porta G, Kenter JAM, Bahamonde JR, Immenhauser A, Villa E (2003) Microbial boundstone dominated carbonate slope (Upper Carboniferous, N Spain): microfacies, lithofacies distribution and stratal geometry. Facies 49:175-208

Della Porta G, Merino-Tomé O, Kenter JAM, Verwer K (2013) Lower Jurassic microbial and skeletal carbonate factories and platform geometry (Djebel Bou Dahar, High Atlas, Morocco). Publication, SEPM Special, p 105

Dragastan O (1969) "Micro-oncolithes" dans le Jurassique supérieur de la vallée du Bicaz (Carpates orientales, Roumanie). Bull Soc géol Fr 7(11):655-659

Dragastan O (2010) Getic Carbonate Platform-Jurassic and Lower Cretaceous stratigraphy, reconstructions, paleogeography, provinces and biodiversity. Ed Univ Bucureşti, 621 pp (in Romanian with English abstract)

Edwards DE, Riding R (1991) Mid-Phanerozoic microskeletal-microbial reef frameworks. In: 5th International symposium on fossil algae, Capri, 7-12 April 1991, abstracts volume, pp 20-21

Flügel E (1981) "Tubiphyten” aus dem fränkischen Malm. Geol B1 Nordost-Bayern angr Gebiete 31:126-142

Flügel E (1994) Pangean shelf carbonates: controls and paleoclimatic significance of Permian and Triassic reefs. Geol Soc Am Special Papers 288:247-266
Flügel E (2002) Triassic reef patterns. In: Kiessling W, Flügel E, Golonka J (eds) Phanerozoic reef patterns. SEPM Special Publication, Tulsa, pp 735-744

Flügel E (2004) Microfacies of carbonate rocks: analysis interpretation and application. Springer, Berlin, p 984

Fürsich FT, Werner W (1991) Palaeoecology of coralline sponge-coral meadows from the Upper Jurassic of Portugal. Paläont Z 65:35-69

Geister J, Lathuilière B, Yudin S (2007) Late Jurassic coral reefs and their paleo-relief at Sudak (South coast of Cromea Peninsula, Ukraine). In: Kossovaya O, Somerville I, Evdokimova I (eds) X International Congress on Fossil Cnidaria and Porifera, August 12-16, 2007, St. Petersburg, Russia-Abstracts: 38. St. Petersburg

Golonka J (2004) Plate tectonic evolution of the southern margin of Eurasia in the Mesozoic and Cenozoic. Tectonophysics 381:235-273

Guo L, Vincent SJ, Lavrishchev V (2011) Upper Jurassic reefs from the Russian western Caucasus: implications for the eastern Black Sea. Turk J Earth Sci 20:629-653

Hoffmann M, Kołodziej B, Skupien P (2017) Microencruster-microbial framework and synsedimentary cements in the Štramberk Limestone (Carpathians, Czech Republic): insights into reef zonation. Ann Soc Geol Polon 87:325-347

Insalaco E, Hallam A, Rosen B (1997) Oxfordian (Upper Jurassic) coral reefs in ester Europe: reef types and conceptual depositional model. Sedimentology 44:707-734

Ivanova D, Kołodziej B, Koleva-Rekalova E, Roniewicz E (2008) Oxfordian to Valanginian palaeoenvironmental evolution on the western Moesian carbonate platform: a case study from SW Bulgaria. Ann Soc Geol Polon 78:65-90

Kaya MY, Altiner D (2015) Microencrusters from the Upper JurassicLower Cretaceous Inalti Formation (Central Pontides, Turkey): remarks on the development of reefal/peri-reefal facies. Facies $61: 18$

Kaźmierczak J, Hillmer G (1974) Sclerosponge nature of the Lower Hauterivian "Bryozoan" Neuropora pustulosa (Roemer, 1839) from Western Germany. Acta Palaeont Polon 19(4):443-453

Kendall AC, Tucker ME (1973) Radiaxial-fibrous calcite: a replacement after acicular carbonate. Sedimentology 20:365-389

Koch R, Schorr M (1986) Diagenesis of Upper Jurassic sponge-algal reefs in SW Germany. In: Schroeder JH, Purser BH (eds) Reef diagenesis. Springer, Berlin, pp 224-244

Kołodziej B (2015) Geological context and age of the Štramberk-type limestones from the Polish Outer Carpathians: an overview. N Jb Geol Paläont Abh 276:173-179

Kosakowski P, Krajewski M (2014) Hydrocarbon potential of the Zechstein Main Dolomite in the western part of the Wielkopolska platform, SW Poland: new sedimentological and geochemical data. Mar Petrol Geol 49:99-120

Krajewski M (2008) Lithology of the Upper Jurassic-Lower Cretaceous (Tithonian-Lower Berriasian) Ay-Petri reef complex (southern Ukraine, the Crimea Mountains). N Jb Geol Paläont Abh 5:298-312

Krajewski M (2010) Facies, microfacies and development of the Upper Jurassic-Lower Cretaceous of the Crimean carbonate platform from the Yalta and Ay-Petri massifs (Crimea Mountain, southern Ukraine). Dissertation Monographs 217 Wydawnictwa AGH, Kraków 253 pp

Krajewski M, Olszewska B (2006) New data about microfacies and stratigraphy of the Late Jurassic Ay-Petri carbonate buildup (south-western Crimea Mountains, South Ukraine). N Jb Geol Paläont Abh, Mh 5:298-312

Krajewski M, Olszewska B (2007) Foraminifera from the Late Jurassic and Early Cretaceous carbonate platform facies of the southern part of the Crimea Mountains, Southern Ukraine. Ann Soc Geol Polon 77:291-311 
Krajewski M, Olchowy P, Felisiak I (2016) Late Jurassic facies architecture of the Złoczew Graben: implications for evolution of the tectonic-controlled northern peri-Tethyan shelf (Upper Oxfordian-Lower Kimmeridgian, Poland). Facies 62:4

Lathuilière B, Gaillard C, Habrant N, Bodeur I, Boullier A, Enay R, Hanzo M, Marchand D, Thierry J, Werner W (2005) Coral zonation of an Oxfordian reef tract in the northern French Jura. Facies 50:545-559

Leinfelder RR, Krautter M, Laternser R, Nose M, Schmid DU, Schweigert G, Werner W, Keupp H, Brugger H, Herrmann R, Rehfeld-Kiefer U, Schroeder JH, Reinhold C, Koch R, Zeiss A, Schweizer V, Christmann H, Menges G, Luterbacher H (1994) The origin of Jurassic reefs: current research developments and results. Facies 31:1-56

Leinfelder RR, Werner W, Nose M, Schmid DU, Krautter M, Laternser R, Takacs M, Hartmann D (1996) Paleoecology, growth parameters and dynamics of coral, sponge and microbialite reefs from the Late Jurassic. Göttinger Arb Geol Paläont Sb 2:227-248

Leinfelder RR, Schmid DU, Nose M, Werner W (2002) Jurassic reef patterns - the expression of a changing globe. In: Kiessling W, Flügel E, Golonka J (eds) Phanerozoic reef patterns. SEPM Spec Publ 72, Tulsa, pp 465-520

Leinfelder R, Schlagintweit F, Werner W, Ebli O, Nose M, Schmid DU, Hughes GW (2005) Significance of stromatoporoids in Jurassic reefs and carbonate platforms - concepts and implications. Facies 51:287-325

Marangon A, Gattolin G, Della Porta G, Preto N (2011) The Latemar: a flat-topped, steep fronted platform dominated by microbialites and synsedimentary cements. Sed Geol 240:97-114

Matyszkiewicz J (1997) Microfacies, sedimentation and some aspects of diagenesis of Upper Jurassic sediments from the elevated part of the Northern peri-Tethyan Shelf: a comparative study on the Lochen area (Schwäbische Alb) and the Cracow area (CracowWielun Upland, Poland). Berliner Geo Abh E 21:1-111

Matyszkiewicz J, Słomka T (2004) Reef-microencrusters association Lithocodium aggregatum - Bacinella irregularis from the Cieszyn limestones (Tithonian-Berriasian) of the Outer Western Carpathians (Poland). Geol Carpath 55:449-456

Matyszkiewicz J, Kochman A, Duś A (2012) Influence of local sedimentary conditions on development of microbialites in the Oxfordian carbonate buildups from the southern part of the Kraków-Częstochowa Upland (south Poland). Sed Geol 263-264:109-132

Mileev VS, Baraboshkin EYu, Rozanov SB, Rogov MA (2006) Kimmerian and Alpine tectonics of Mountain Crimea. (English summary). Bull Moscow Soc Natur Geol Ser 8:22-33

Muratov M.V. 1973. Geology of the Crimea Peninsula. (in Russian), vol. 2, Moskva $191 \mathrm{pp}$

Nikishin AM, Okay A, Tuysüz O, Demirer A, Wannier M, Amelin N, Petrov E (2015a) The Black Sea basins structure and history: new model based on new deep penetration regional seismic data. Part 2: tectonic history and paleogeography. Mar Petrol Geol 59:656-670

Nikishin AM, Wannier M, Alekseev AS, Almendinger OA, Fokin PA, Gabdullin RR, Khudoley AK, Kopaevich LF, Mityukov AV, Petrov EI, Rubtsova EV (2015b) Mesozoic to recent geological history of southern Crimea and the Eastern Black Sea region. In: Sosson M, Stephenson RA, Adamia SA (eds) Tectonic Evolution of the Eastern Black Sea and Caucasus. Geological Society, Spec Pub 428, London, pp 241-264

Ohga H, Kołodziej B, Nose M, Schmid DU, Takayanagi H, Iryu Y (2013) Sedimentary facies and biofacies of the Torinosu Limestone in the Torinosu area, Kochi Prefecture, Japan. Island Arc 22(2):150-169. https://doi.org/10.1111/iar.12009
Olchowy P (2011) Possible origin of stromatactis-like cavities in Upper Jurassic sediments from the Wielkanoc quarry near Gołcza (Kraków-Częstochowa Upland, southern Poland)—experimental studies. Facies 57:613-625

Oszczypko N, Ślączka A, Bubniak I, Olszewska B, Garecka M (2017) The position and age of flysch deposits in the Crimean Mountains (Southern Ukraine). Geol Quart 61:697-722

Payne JL, Lehrmann DJ, Christensen S, Wei J, Knoll AH (2006) Environmental and biological controls on the initiation and growth of a Middle Triassic (Anisian) Reef Complex on the Great Bank of Guizhou, Guizhou Province, China. Palaios 21:325-343

Piskunov VK, Rud'ko SV, Eyu B (2012) The sedimentary conditions of Middle-Upper Tithonian limestones of the Bererdzhi Plateau (Mountain Crimea). Mosc Univ Geol Bull 67:273-281

Pleş G, Mircescu CV, Bucur II, Săsăran E (2013) Encrusting microorganisms and microbial structures in Upper Jurassic limestones from the Southern Carpathiana (Romania). Facies 59:19-48

Pleş G, Bârtaş T, Chelaru R, Bucur II (2017) Crescentiella morronensis (Crescenti) (incertae sedis) dominated microencruster association in Lower Cretaceous (lower Aptian) limestones from Rarău Massif (Eastern Carpathians, Romania). Cretac Res 79:91-108

Pomoni-Papaioannou PF, Flügel E, Koch R (1989) Depositional environments and diagenesis of Upper Jurassic subsurface sponge- and Tubiphytes reef limestones: Altensteig 1 well, western Mollase Basin, southern Germany. Facies 21:263-284

Popa L, Panaiotu CE, Grădinaru E (2014) An early Middle Anisian (Middle Triassic) Tubiphytes and cement crusts-dominated reef from North Dobrogea (Romania): facies, depositional environment and diagenesis. Acta Geol Polon 64:189-206

Riding R (2002) Structure and composition of organic reefs and carbonate mud mounds: concepts and categories. Earth Sci Rev $58: 163-231$

Rud'ko SV, Kuznetsov AB, Piscunov VK (2014) Sr isotope chemostratigraphy of Upper Jurassic carbonate rocks in the Demerdzhi Plateau (Crimean Mountains). Strat Geol Correl 22:494-506

Rud'ko SV, Kuznetsov AB, Pokrovsky BG (2017) Sr chemostratigraphy, delta C-13, and delta O-18 of rocks in the Crimean Carbonate Platform (Late Jurassic, Northern Peri-Tethys). Litho Min Res 52:479-497

Rusciadelli G, Ricci C, Lathuilière B (2011) The Ellipsactinia Limestones of the Marsica area (Central Apennines): a reference zonation model for Upper Jurassic Intra-Tethys reef complexes. Sed Geol 233:69-87

Saller AH, Harris PM, Kirkland BL, Mazzullo SJ (1999) Geologic framework of the Capitan reef. SEPM Special Publication, California, $\mathrm{p} 65$

Schlagintweit F, Gawlick HJ (2008) The occurrence and role of microencruster frameworks in Late Jurassic to Early Cretaceous platform margin deposits of the Northern Calcareous Alps (Austria). Facies 54:207-231

Schlagintweit F, Gawlick HJ (2009) Enigmatic tubes associated with microbial crusts from the Late Jurassic of the Northern Calcareous Alps (Austria): a mutualistic sponge-epibiont consortium? Lethaia 42:452-461

Schlagintweit F, Krajewski (2015) Sarmentofascis? digitatus n. sp., a new cladocoropsid stromatoporoid from the Tithonian-early Berriasian (Late Jurassic-Early Cretaceous) of the Ay-Petri massif (Crimea Peninsula). N Jb Geol Paläont Abh 277:141-151

Schmid DU (1995) “Tubiphytes" morronensis-eine fakultativ inkrustierende Foraminifere mit endosymbiontischen Algen. Profil $8: 305-317$

Schmid DU (1996) Marine Mikrobolithe und Mikroinkrustierer aus dem Oberjura. Profil 9:101-251

Seeling M, Emmerich A, Bechstädt T, Zühlke R (2005) Accommodation/sedimentation development and massive early marine 
cementation: Latemar vs. Concarena (Middle/Upper Triassic, Southern Alps). Sed Geol 175:439-457

Senowbari-Daryan B (2013) Tubiphytes Maslov, 1956 and description of similar organisms from Triassic reefs of the Tethys. Facies 59:75-112

Senowbari-Daryan B, Zühlke R, Bechstädt T, Flügel E (1993) Anisian (Middle Triassic) buildups of the northern Dolomites (Italy): the recovery of the reef communities after the Permian/Triassic crisis. Facies 28:181-256

Senowbari-Daryan B, Bucur II, Schlagintweit F, Săsarăn E, Matyszkiewicz J (2008) Crescentiella, a new name for "Tubiphytes" morronensis Crescenti, 1969: an enigmatic Jurassic-Cretaceous microfossil. Geol Croatica 61(1-2):185-214

Shiraishi F, Kano A (2004) Composition and spatial distribution of microencrusters and microbial crusts in upper Jurassic-lowermost Cretaceous reef limestone (Torinosu Limestone, southwest Japan). Facies 50(2):217-227

Strzeboński P, Kowal-Kasprzyk J, Olszewska B (2017) Exotic clasts, debris flow deposits and their significance for reconstruction of the Istebna Formation (Late Cretaceous-Paleocene, Silesian Basin, Outer Carpathians). Geol Carpath 68:562-582

Termier G, Termier H, Ramalho M (1985) Spongiofaunes du Jurassique Supérieur du Portugal. Com Serv Geol Portugal 71(2):197-222
Turnšek D, Buser S, Ogorolec B (1981) An Upper Jurassic reef complex from Slovenia, Yugoslavia. In: Toomey DF (ed) European Fossil Reef models. Soc Econom Paleont Min Special Publication, Tulsa, pp 361-369

Utã A, Bucur II (2003) Microbial structures and microencrusters in the Upper Jurassic-Lower Cretaceous deposits from Buila-Vânturaripa Massif (South Carpathians). Stud Univ Babeş-Bolyai Geol 48:3-14

Vincent SJ, Guo L, Flecker R, BouDagher-Fadel MK, Ellam RM, Kandemir R (2018) Age constraints on intra-formational unconformities in Upper Jurassic-Lower Cretaceous carbonates in northeast Turkey; geodynamic and hydrocarbon implications. Mar Petrol Geol 91:639-657

Vlahović I, Tisljar J, Velic I, Maticec D (2005) Evolution of the Adriatic carbonate platform: palaeogeography, main events and depositional dynamics. Palaeogeo Palaeoclim Palaeoeco 220:333-360

Weidlich O (2002) Middle and Late Permian reefs_-distributional patterns and reservoir potential. In: Kiessling W, Flügel E, Golonka J (eds) Phanerozoic Reef Patterns. SEPM Special Publication 72, Tulsa, pp 339-390

Wood R (1999) Reef evolution. Oxford University Press, Oxford, p 354

Yudin VV, Arkadiev VV, Yurovsky YuG (2015) "Revolution" in geology of Crimea (in Russian with English summary). Viestnik SPGU 7:25-37 